\title{
Literature Survey for
}

Groundwater Treatment

Options for Nitrate,

lodine-129, and Uranium,

200-ZP-1 Operable Unit,

Hanford Site

Prepared for the U.S. Department of Energy

Assistant Secretary for Environmental Management

Project Hanford Management Contractor for the

U.S. Department of Energy under Contract DE-AC06-96RL13200

\section{FLUOR.}

P.O. Box 1000

Richland, Washington

Approved for Public Release:

Further Dissemination Unhimited 
SGW-37783

Revision 0

\title{
Literature Survey for Groundwater Treatment Options for Nitrate, lodine-129, and Uranium, 200-ZP-1 Operable Unit, Hanford Site
}

\author{
J. A. Kalmar
}

Landau Associates

M. E. Byrnes

Fluor Hanford, Inc.

Date Published

May 2008

Prepared for the U.S. Department of Energy

Assistant Secretary for Environmental Management

Project Hanford Management Contractor for the

U.S. Department of Energy under Contract DE-AC06-96RL13200

\section{FLUOR.}

P.O. Box 1000

Richland, Washington

SGW-37783

Revision 0

TRADEMARK DISCLAIMER

Reference herein to any specific commercial product, process,

or service by trade name, trademark, manufacturer, or

otherwise, does not necessarily constitute or imply its

endorsement, recommendation, or favoring by the United

States Government or any agency thereof or its contractors or subcontractors.

This report has been reproduced from the best available copy.

Printed in the United States of America 


\section{TABLE OF CONTENTS}

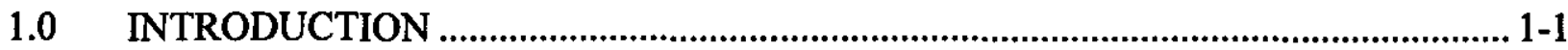

$1.1 \quad$ BACKGROUND INFORMATION ............................................................

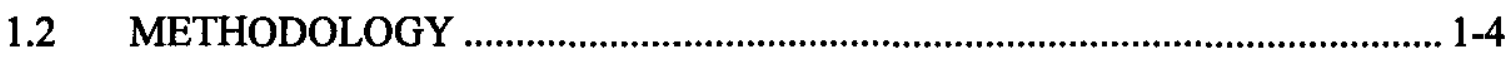

CHEMICAL PROPERTIES OF NITRATE, IODINE-129, AND
URANIUM …................................................................................ 1-5

2.0 DESCRIPTION OF TECHNOLOGIES .................................................................... 2-1

2.1 EX SITU TREATMENT (PUMP-AND-TREAT) ……………............................ 2-1

2.1.1 Physical/Chemical................................................................................ 2-1

2.1.2 Biological Treatment ........................................................................... 2-2

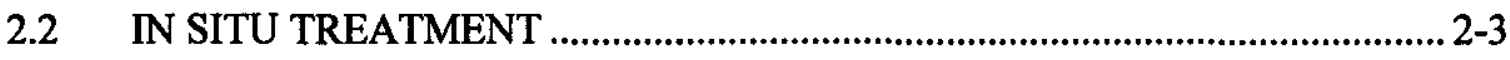

2.2.1 Permeable Reactive Barriers................................................................ 2-3

2.2.2 Anaerobic Bioremediation .................................................................... 2-3

2.2.3 Inorganic Immobilization....................................................................... 2-4

$3.0 \quad$ NITRATE TREATMENT OPTIONS …..................................................................

3.1 EX SITU TREATMENT (PUMP-AND-TREAT) …......................................... 3-1

3.1.1 Physical/Chemical Treatment ...................................................................... 3-1

3.1.2 Biological ...................................................................................... 3-2

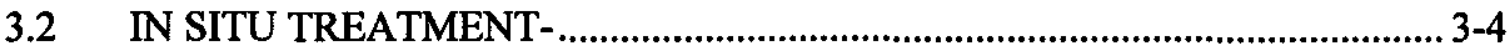

3.2.1 Permeable Reactive Barriers................................................................. 3-5

3.2.2 Anaerobic Bioremediation ................................................................. 3-5

4.0 IODINE-129 TREATMENT OPTIONS .................................................................... 4-1

4.1 EX SITU TREATMENT (PUMP-AND-TREAT) ……...................................... 4-1

4.1.1 Physical/Chemical Treatment ...................................................................... 4-1

4.2 IN SITU TREATMENT ........................................................................ 4-2

5.0 URANIUM TREATMENT OPTIONS ……...........................................................

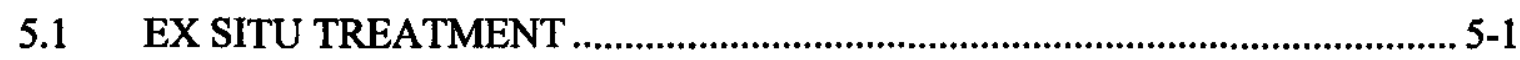

5.1.1 Physical/Chemical Treatment .............................................................5-1

5.1.2 Biological Treatment ............................................................................ 5-1

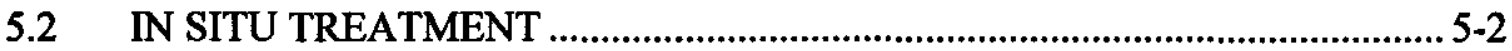

5.2.1 Anaerobic Bioremediation ................................................................. 5-2

5.2.2 Permeable Reactive Barriers................................................................ 5-3

5.2.3 Immobilization.............................................................................. 5-4 
SGW-37783, Rev. 0

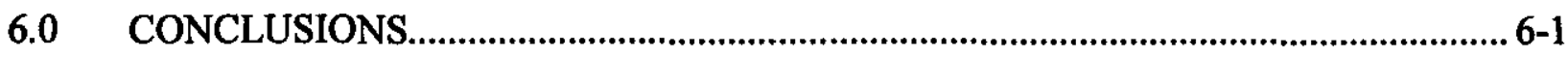

6.1 APPLICABLE NITRATE TREATMENT TECHNOLOGIES............................. 6-1

6.2 APPLICABLE IODINE-129 TREATMENT TECHNOLOGIES........................ 6-1

6.3 APPLICABLE URANIUM TREATMENT TECHNOLOGIES ......................... 6-2

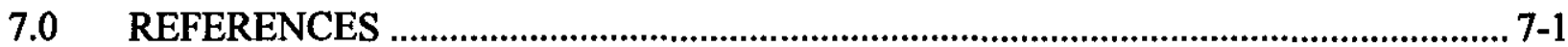

\section{FIGURES}

Figure 1-1. Estimated Lateral Extent of Nitrate in Groundwater. ................................................ 1-3

Figure 1-2. Estimated Lateral Extent of Iodine-129 in Groundwater......................................... 1-3

Figure 1-3. Estimated Lateral Extent of Uranium in Groundwater. .......................................... 1-4

\section{TABLE}

Table 1-1. Summary of Contaminants of Potential Concern for the 200-ZP-1

Groundwater Operable Unit. 


\section{LIST OF TERMS}

$\begin{array}{ll}\text { AFO } & \text { amorphous ferric oxyhydroxide } \\ \text { COC } & \text { contaminant of concern } \\ \text { COPC } & \text { contaminants of potential concern } \\ \text { DOE } & \text { U.S. Department of Energy } \\ \text { DWS } & \text { drinking water standard } \\ \text { EPA } & \text { U.S. Environmental Protection Agency } \\ \text { GAC } & \text { granular activated carbon } \\ \text { gpm } & \text { gallons per minute } \\ \text { HRC } & \text { Hydrogen Release Compound } \\ \text { IX } & \text { ion exchange } \\ \text { MCL } & \text { maximum contaminant level } \\ \text { MNA } & \text { monitored natural attenuation } \\ \text { OU } & \text { operable unit } \\ \text { PRB } & \text { permeable reactive barrier } \\ \text { ROD } & \text { Record of Decision } \\ \text { SIAC } & \text { silver-impregnated activated carbon } \\ \text { TCE } & \text { trichloroethylene } \\ \text { WMA } & \text { waste management area } \\ \text { WRT } & \text { Water Remediation Technology, LLC }\end{array}$


SGW-37783, Rev. 0

This page intentionally left blank. 


\section{METRIC CONVERSION CHART}

\begin{tabular}{|c|c|c|c|c|c|}
\hline \multicolumn{3}{|c|}{ Into Metric Units } & \multicolumn{3}{|c|}{ Out of Metric Units } \\
\hline If You Know & Multiply By & To Get & If You Know & Multiply By & To Get \\
\hline Length & & & Length & & \\
\hline inches & 25.4 & millimeters & millimeters & 0.039 & inches \\
\hline inches & 2.54 & centimeters & centimeters & 0.394 & inches \\
\hline feet & 0.305 & meters & meters & 3.281 & feet \\
\hline yards & 0.914 & meters & meters & 1.094 & yards \\
\hline miles & 1.609 & kilometers & kilometers & 0.621 & miles \\
\hline Area & & & Area & & \\
\hline sq. inches & 6.452 & sq. centimeters & sq. centimeters & 0.155 & sq. inches \\
\hline sq. feet & 0.093 & sq. meters & sq. meters & 10.76 & sq. feet \\
\hline sq. yards & 0.836 & sq. meters & sq. meters & 1.196 & sq. yards \\
\hline sq. miles & 2.6 & sq. kilometers & sq. kilometers & 0.4 & sq. miles \\
\hline acres & 0.405 & hectares & hectares & 2.47 & acres \\
\hline Mass (weight) & & & Mass (weight) & & \\
\hline ounces & 28.35 & grams & grams & 0.035 & ounces \\
\hline pounds & 0.454 & kilograms & kilograms & 2.205 & pounds \\
\hline ton & 0.907 & metric ton & metric ton & 1.102 & ton \\
\hline Volume & & & Volume & & \\
\hline teaspoons & 5 & milliliters & milliliters & 0.033 & fluid ounces \\
\hline tablespoons & 15 & milliliters & liters & 2.1 & pints \\
\hline fluid ounces & 30 & milliliters & liters & 1.057 & quarts \\
\hline cups & 0.24 & liters & liters & 0.264 & gallons \\
\hline pints & 0.47 & liters & cubic meters & 35.315 & cubic feet \\
\hline quarts & 0.95 & liters & cubic meters & 1.308 & cubic yards \\
\hline gallons & 3.8 & liters & & & \\
\hline cubic feet & 0.028 & cubic meters & & & \\
\hline cubic yards & 0.765 & cubic meters & & & \\
\hline Temperature & & & Temperature & & \\
\hline Fahrenheit & $\begin{array}{l}\text { subtract } 32 \text {, } \\
\text { then } \\
\text { multiply by } \\
5 / 9\end{array}$ & Celsius & Celsius & $\begin{array}{l}\text { multiply by } \\
9 / 5 \text {, then add } \\
32\end{array}$ & Fahrenheit \\
\hline $\begin{array}{l}\text { Radioactivity } \\
\text { picocuries }\end{array}$ & 37 & millibecquerels & $\begin{array}{l}\text { Radioactivity } \\
\text { millibecquerels }\end{array}$ & 0.027 & picocuries \\
\hline
\end{tabular}


SGW-37783, Rev. 0

This page intentionally left blank. 


\section{$1.0 \quad$ INTRODUCTION}

This literature review presents treatment options for nitrate, iodine-129, and uranium, which are present in groundwater at the 200-ZP-1 Groundwater Operable Unit (OU) within the 200 West Area of the Hanford Site. The objective of this review is to determine available methods to treat or sequester these contaminants in place (i.e., in situ) or to pump-and-treat the groundwater aboveground (i.e., ex situ). This review has been conducted with emphasis on commercially available or field-tested technologies, but theoretical studies have, in some cases, been considered when no published field data exist. The initial scope of this literature review included only nitrate and iodine-129, but it was later expanded to include uranium. The focus of the literature review was weighted toward researching methods for treatment of nitrate and iodine-129 over uranium because of the relatively greater impact of those compounds identified at the 200-ZP-1 OU.

\subsection{BACKGROUND INFORMATION}

The Hanford Site covers approximately $943 \mathrm{~km}^{2}\left(586 \mathrm{mi}^{2}\right)$. Past nuclear weapons production activities at the Site resulted in approximately 1.7 trillion L ( 450 billion gal) of liquid waste being released to the ground. Hazardous chemical contaminants include carbon tetrachloride, trichloroethylene (TCE), chromium, and nitrate. Radioactive contaminants include iodine-129, strontium-90, technetium-99, tritium, and uranium. The 200-ZP-1 Groundwater OU is one of two groundwater OUs located within the 200 West groundwater aggregate area of the Hanford Site. The 200-ZP-1 OU underlies the northern portion of the 200 West Area, including Z Plant, T Plant, Low-Level Waste Management Areas 3 and 4, 241-T Tank Farm, 241-TX/TY Tank Farms, the State-Approved Land Disposal Site, and various cribs and trenches receiving liquid waste.

Only carbon tetrachloride was identified to exceed a $1 \times 10^{-4}$ risk level and was the only contaminant identified in the Feasibility Study Report for the 200-ZP-1 Groundwater Operable Unit (DOE/RL-2007-28) as a contaminant of concern (COC) and a principal threat. Other contaminants of potential concern (COPCs) and their percentile concentrations in 200-ZP-1 OU groundwater were also presented in the feasibility study (DOE/RL-2007-28) and are listed in Table 1-1.

Groundwater pump-and treat was implemented at the 200-ZP-1 OU as an interim remedial action based on the Declaration of the Interim Record of Decision for the 200-ZIP-1 Operable Unit (EPA et al. 1995). The objectives of the interim action Record of Decision (ROD) were to prevent further migration of carbon tetrachloride-contaminated groundwater and to reduce contaminant mass in the aquifer. The current treatment system extracts approximately $1,591 \mathrm{~L} / \mathrm{min}$ ( 350 gallons per minute [gpm]) of carbon tetrachloride-contaminated groundwater, and treatment consists of using a combination of air stripping and granular activated carbon (GAC) to collect the vapor-phase contaminants. The treated liquid effluent is reinjected into the aquifer upgradient of the extraction wells. 
Table 1-1. Summary of Contaminants of Potential Concern for the 200-ZP-1 Groundwater Operable Unit.

\begin{tabular}{|l|c|c|c|c|}
\hline \multirow{2}{*}{ COPC } & \multicolumn{3}{|c|}{ Percentiles } & \multirow{2}{*}{ Units } \\
\cline { 2 - 4 } & $25^{\text {th }}$ & $5^{\text {th }}$ & $9^{\text {th }}$ & \multirow{2}{*}{} \\
\hline Carbon tetrachloride & 6.53 & 505 & 2,900 & $\mu \mathrm{g} / \mathrm{L}$ \\
\hline Chloroform & 0.58 & 6.40 & 24 & $\mu \mathrm{g} / \mathrm{L}$ \\
\hline Total chromium & 3.6 & 10.3 & 130 & $\mu \mathrm{g} / \mathrm{L}$ \\
\hline Chromium (VI) & 7 & 10.9 & 203.4 & $\mu \mathrm{g} / \mathrm{L}$ \\
\hline Methylene chloride & 0.12 & 0.185 & 2.734 & $\mu \mathrm{g} / \mathrm{L}$ \\
\hline Nitrate as nitrogen & 14,000 & 21,900 & 81,050 & $\mu \mathrm{g} / \mathrm{L}$ \\
\hline Tetrachloroethylene (PCE) & 0.18 & 0.36 & 2.5 & $\mu \mathrm{g} / \mathrm{L}$ \\
\hline Trichloroethylene (TCE) & 0.155 & 1.7 & 10.9 & $\mu \mathrm{g} / \mathrm{L}$ \\
\hline Uranium & 0.74 & 1.17 & 5.06 & $\mu \mathrm{g} / \mathrm{L}$ \\
\hline Iodine-129 & $<0.025$ & 0.03 & 1.17 & $\mathrm{pCi} / \mathrm{L}$ \\
\hline Technetium-99 & 54.1 & 173 & 1,436 & $\mathrm{pCi} / \mathrm{L}$ \\
\hline Tritium & 513.75 & 3,605 & 36,200 & $\mathrm{pCi} / \mathrm{L}$ \\
\hline
\end{tabular}

NOTE: The "less than" symbol $(<)$ indicates a nondetected value. COPC $=$ contaminant of potential concern

The nitrate at the 200-ZP-1 OU is from multiple sources and exceeds the Federal drinking water standard (DWS) maximum contaminant level (MCL) of $10 \mathrm{mg} / \mathrm{L}$ over a large area (Screening of Potential Remediation Methods for the 200-ZP-1 Operable Unit at the Hanford Site [PNNL-15954]; DOE/RL-2007-28), as shown in Figure 1-1. Iodine-129 concentrations exceed the $1 \mathrm{pCi} / \mathrm{L}$ implementation guidance for radionuclides (Implementation Guidance for Radionuclides [EPA 816-F-00-002]) near Waste Management Area T (WMA-T) extending northeast, and also east of WMA-TX/TY (DOE/RL-2007-28), as shown in Figure 1-2. The uranium plume exceeds the MCL of $30 \mu \mathrm{g} / \mathrm{L}$ north and northeast of WMA-T (DOE/RL-2007-28), as shown in Figure 1-3. In terms of plume size and extent, the uranium groundwater plume that exceeds the MCL is smaller than (and is located completely within) the larger iodine-129 plume that exceeds $1 \mathrm{pCi} / \mathrm{L}$. The iodine- 129 plume that exceeds $1 \mathrm{pCi} / \mathrm{L}$, in turn, is smaller than (and is located completely within) the larger nitrate plume that exceeds the nitrate MCL. 
SGW-37783, Rev. 0

Figure 1-1. Estimated Lateral Extent of Nitrate in Groundwater.

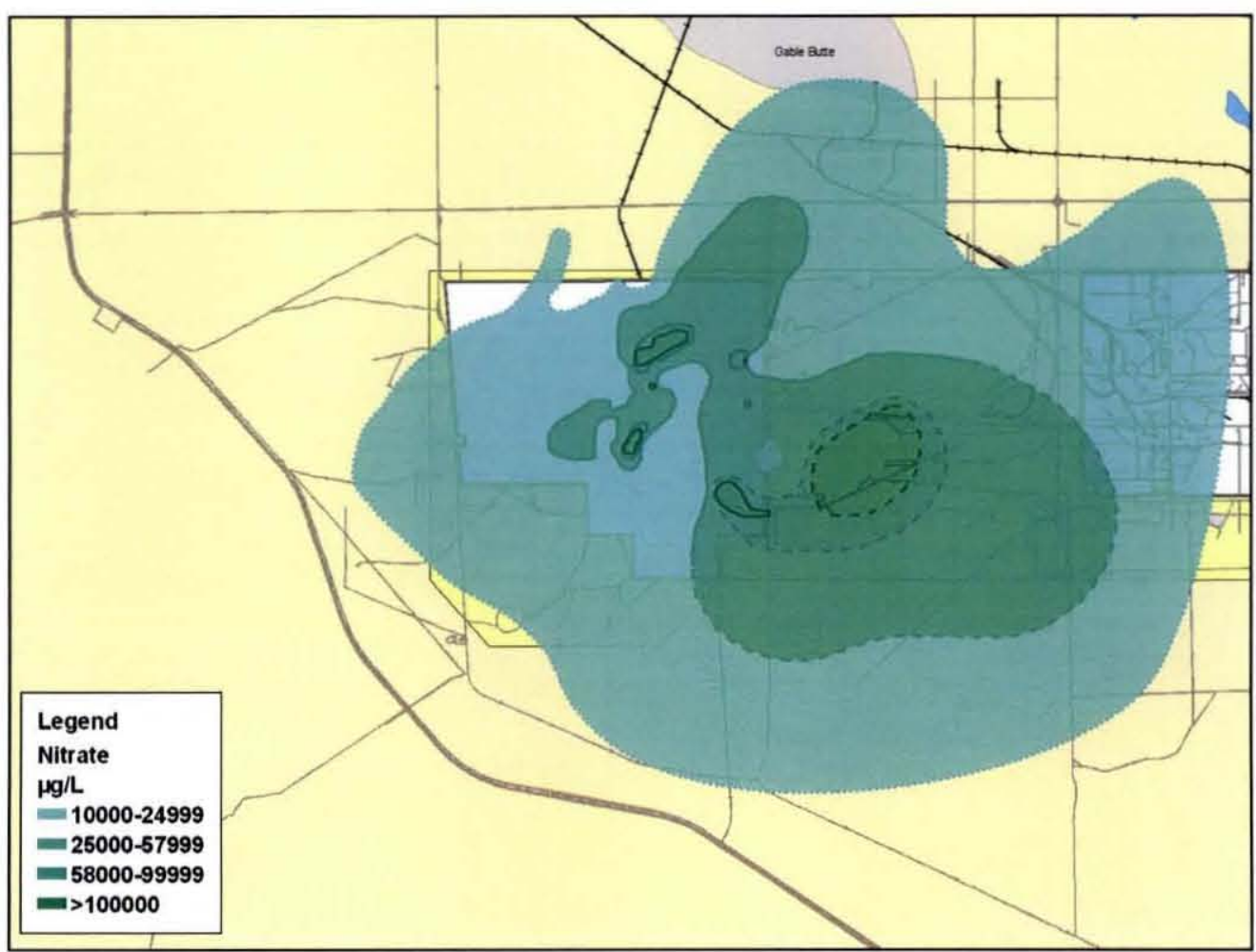

Figure 1-2. Estimated Lateral Extent of Iodine-129 in Groundwater.




Figure 1-3. Estimated Lateral Extent of Uranium in Groundwater.



SOURCE: This figure was obtained from the Feasibility Study Report for the 200-ZP-1 Groundwater Operable Unit (DOE/RL-2007-28).

\subsection{METHODOLOGY}

This literature survey focuses on commercially available technologies and/or technologies that have been implemented or at least tested at a site. If these types of demonstrated technologies were not found for a particular COPC, then other technologies with promising bench-test data or that have been evaluated to be theoretically viable and effective are presented here.

This review was performed through extensive research of the published literature and through contacting technology vendors. Articles were identified and reviewed based on keyword searches of multiple publications including, but not limited to, the following publications:

- Applied and Environmental Microbiology

- Atomic Energy

- Applied Geochemistry

- Applied Surface Science

- Biodegradation

- Chemical Communications

- Chemical Engineering Science

- Desalination

- Ecological Engineering

- Environmental Microbiology
- Groundwater Remediation

- International Journal of Environmental Science and Technology

- Journal American Water Works Association

- Journal of Contaminant Hydrology

- Journal of Environmental Health and Science

- Journal of the Chemical Society

- Journal of Hazardous Materials

- Journal of Environmental Engineering 
- Environmental Pollution

- Environmental Science

- Environmental Science and Technology

- Environmental Trend and Technology

- Federal Facilities Environmental Journal

- Ground Water

- Groundwater Monitoring and Remediation
- Nature

- Radiochemica Acta

- Reactive and Functional Polymers

- Separation and Purification Technology

- The Science of the Total Environment

- Water Research

- Water Resources

- Water Science and I'echnology

The literature search also included Interstate Technology \& Regulatory Council documents; United Kingdom Environmental Agency reports; books; proceedings of the $7^{\text {th }}$ and $9^{\text {th }}$ International In Situ and On-Site Bioremediation Symposiums; Hazardous Waste Clean-Up Information website; citation databases such as Environmental Sciences and Pollution Management, Web of Science, and Energy Citations Database; various reports from the U.S. Geological Survey and Pacific Northwest National Laboratory (PNNL); and reports published for the Hanford 200 West Area (DOE/RL-2007-28; Remedial Investigation Report for the 200-ZP-1 Groundwater Operable Unit [DOE/RL-2006-24]). Besides these publications, many other publications were searched but are not listed here if articles of no potential interest were found. Vendors and organizations contacted through e-mail and phone include, but are not limited to, the following: PNNL; the U.S. Environmental Protection Agency (EPA); Siemens Corporation; Purolite Corporation (Purolite), Remco Engineering (Remco); Water Remediation Technology, LLC (WRT); and General Electric Water \& Process Technologies. A reference list is included in Section 7.0 for those articles cited in this document that were considered relevant to the criteria of this literature search. Other articles that may have discussed the treatment of nitrate, iodine-129, or uranium but were not deemed relevant for evaluation at the Hanford Site are not listed in the reference section.

\subsection{CHEMICAL PROPERTIES OF NITRATE, IODINE-129, AND URANIUM}

This section briefly describes the chemical properties of nitrate, iodine-129, and uranium present at the Hanford Site. Chemical properties such as oxidation state and solubility are important because they will impact the effectiveness of the potential treatment technologies.

Nitrate $\left(\mathrm{NO}_{3}{ }^{-}\right)$is an anion that is stable, very soluble, and very mobile under aerobic conditions. Nitrogen can be found in various oxidation states, such as ammonia, $\mathrm{NH}_{3}(-3)$, nitrite, $\mathrm{NO}_{2}{ }^{-}(+3)$, and nitrate, $\mathrm{NO}_{3}{ }^{-}(+5)$. Nitrate is the most oxidized form of nitrogen and cannot be further oxidized, but it can be reduced and transformed under anaerobic conditions. Under anaerobic conditions, nitrate can sequentially be degraded to the end product nitrogen gas $\left(\mathrm{N}_{2}\right)$, in the presence of a carbon source and/or ion sulfides (Attenuation of Nitrate in the sub-Surface Environment [Environment Agency 2005]). Under the aerobic conditions present in the groundwater at Hanford, nitrate is stable and will not be degraded.

Iodine has several oxidation states depending on groundwater conditions. The chemical form of iodine is dependent on $\mathrm{pH}$ and reduction/oxidation conditions in the environment. In typical groundwater environments, the most common forms are iodide $\left(\mathrm{I}^{-}\right)$, diiodine $\left(\mathrm{I}_{2}\right)$, and iodate $\left(\mathrm{IO}_{3}{ }_{3}\right)$ (Potential In Situ Remediation of ${ }^{129}$ I and ${ }^{99} \mathrm{Tc}$ in Groundwater Associated with the F-Area Seepage Basins (U) [WSRC-TR-2002-00571]). Diiodine is only formed under acidic $(\mathrm{pH}<4.5)$ and oxidizing conditions, iodate is only formed under only very oxidizing conditions but under 
all $\mathrm{pH}$ levels, and iodide is present under all $\mathrm{pH}$ levels under reducing to oxidizing conditions (WSRC-TR-2002-00571). Because the groundwater at the 200 West Area generally has a pH much higher than 4.5 , it is anticipated that iodine is not present in the form of diiodine, and is likeliest in the form of iodide. Iodine-129 contains two more neutrons and is radioactive (with an approximate half-life of 15.7 million years) compared to the predominant and stable form of iodine, which is iodine-127; however, iodine-129 is otherwise considered to have the same chemical properties as iodine-127. Therefore, technologies with documented success or theoretical ability to treat iodine-127 can be estimated to be equally effective in treating iodine-129.

In nature, uranium exists as several isotopes: primarily uranium-238 (half-life of 4.5 billion years), uranium-235 (half-life of 704 billion years), and a very small amount of uranium-234 (half-life of 244,000 years). In addition to the three naturally occurring isotopes, uranium-232, uranium-233, and uranium-236 are present at Hanford as well (EVS Human Health Fact Sheet [ANL 2005]). Relative isotopic concentrations for uranium-234, uraniurn-235, and uranium-238 at Hanford are estimated in the risk assessment report to be the same as their natural abundance. Uranium has several possible oxidation states but generally appears in groundwater as the mobile hexavalent uranium (VI) under aerobic conditions, which are the conditions present at the Hanford 200 West Area. Uranium can be reduced to uranium (IV) under anaerobic conditions and precipitate as uraninite $\left(\mathrm{UO}_{2}\right)$, which is an immobile solid form. 
SGW-37783, Rev. 0

\subsection{DESCRIPTION OF TECHNOLOGIES}

This section provides a general description of relevant technologies identified in this literature review for treatment of the contaminants nitrate, iodine-129, and uranium.

\subsection{EX SITU TREATMENT (PUMP-AND-TREAT)}

Pump-and-treat can be used for either containment of contaminants in the source zone or for complete remediation of the groundwater aquifer, depending on the site conditions. Pump-andtreat is a very common remediation technology that has been used for a wide range of mobile contaminants in groundwater.

Use of pump-and-treat involves groundwater extraction from an appropriate number and spacing of extraction wells to prevent downgradient migration beyond points of compliance. An aboveground groundwater treatment system is installed to treat contaminants to achieve the established treatment and discharge standards. Reinjection of treated water is sometimes incorporated into the design of a pump-and-treat system to manipulate hydraulic gradients and improve containment.

Pump-and-treat for aquifer treatment refers to groundwater extraction and ex situ treatment to remove contaminant mass from the aquifer. This differs from pump-and-treat for hydraulic containment in that groundwater extraction is performed in the highest concentration areas and at a higher flow rate to maximize contaminant mass removal. Although containment may also result, the primary objective is to speed restoration of the aquifer. Pump-and-treat for aquifer treatment and for containment may be applied in different areas of the plume.

Pump-and-treat has been widely implemented as a groundwater remedy for containment and/or treatment. Based on a review of National Priorities List sites, pump-and-treat was part of the remedy or the sole remedy at $67 \%$ (713 of 1,062 sites) of all groundwater treatment RODs written between fiscal years 1982 and 2002 (Treatment Technologies for Site Cleanup: Annual Status Report [EPA-542-R-03-009]), representing the most common groundwater remedial action.

\subsubsection{Physical/Chemical}

Physical and chemical removal technologies are commonly used in combination with pump-andtreat. These treatment technologies include ion exchange (IX), GAC, reverse osmosis, and electrodialysis.

2.1.1.1 Ion Exchange. The process using IX consists of using a resin to adsorb and retain anionic or cationic contaminants from groundwater and releasing benign anions or cations in their place. The resin becomes saturated when all of the resin's functional groups have been occupied, at which point the resin needs to be recharged before reuse, or possibly disposed and replaced. The IX resins are typically recharged with a strong acid, base, or salt solution, and a wastewater stream will be generated that requires additional treatment either onsite or offsite. Strong-base anionic-exchange resins are, for example, used for the removal of nitrate. When groundwater flows over the resin, the nitrate anion is exchanged with a chloride or bicarbonate ion residing on the resin. The use of IX resin has been previously tested at the Hanford Site's 200-ZP-1 OU for the removal of technetium-99. 
2.1.1.2 Granular Activated Carbon. A process using GAC can be used to adsorb and remove aqueous-phase contaminants from groundwater, in addition to its use for treatment of air streams. Activated carbon contains a large surface area per volume for adsorption of contaminants and is typically effective in groundwater applications for removing organic contaminants with limited solubility in water. Spent activated carbon is typically thermally reactivated at an offsite facility and can be reused following reactivation.

2.1.1.3 Electrodialysis. Electrodialysis is a membrane filtration technique that is widely used as a desalination method (i.e., production of potable water from marine or brackish water). This method uses an electric potential gradient to move ions through permeable ion membranes. The electric current moves ions from a less concentrated solution to a more concentrated solution, which is possible due to the membranes that only allow either positively or negatively charged ions to pass. The contaminants are concentrated into a liquid waste stream. The concentrated waste liquid would then typically need to undergo further onsite treatment or be sent offsite for treatment and/or disposal.

2.1.1.4 Reverse Osmosis. Reverse osmosis is a membrane filtration technology that involves pumping water through a low-permeability membrane at relatively high pressure in order to remove contaminants. As with electrodialysis, reverse osmosis is widely used as a desalination method to produce drinking water, and the concentrated waste liquid that is generated typically undergoes further onsite treatment or is sent offsite for treatment and/or disposal.

\subsubsection{Biological Treatment}

Biological ex situ treatment alternatives are technologies where the groundwater is pumped up to the surface into a bioreactor or constructed wetland. The contaminants are then degraded by biological media, such as micro-organisms on a bio-film or in the root systems of plants. Several removal mechanisms have been identified with biological treatment of nitrate in water such as decomposition, nitrification/denitrification, settling, volatilization, adsorption, and nutrient uptake ("Performance of Constructed Wetland Treating Wastewater frorn Seafood Industry" [Yirong and Puetpaiboon 2004]).

A bioreactor used for groundwater treatment would generally consist of a fixed media with large surface area in a vessel or structure used to support micro-organism growth. Typically the groundwater being treated does not provide an adequate food source or optimal water conditions to sustain and promote biological treatment; therefore, supplemental nutrients are typically added to the influent groundwater to provide a carbon source for energy and cell growth substrate and to optimize the biological treatment process. For example, to create an anaerobic bioreactor for treatment of aerobic groundwater, a soluble carbon source (e.g., acetic acid, methanol, or ethanol) would be added to influent groundwater as an energy source and to establish reducing and anoxic conditions.

Constructed wetlands can be described as artificial swamps that act as biofilters for removing contaminants and are common processes in wastewater treatment. A constructed wetland provides several removing mechanisms such as decomposition, nitrification/denitrification, settling, volatilization, adsorption, and nutrient uptake (Yirong and Puetpaiboon 2004). A constructed wetland would typically require a much larger area and a much longer hydraulic retention time compared to a bioreactor, but it typically would not require added nutrients and would require less operational oversight. 
SGW-37783, Rev. 0

\section{$2.2 \quad$ IN SITU TREATMENT}

A review of literature for in situ remediation methods for nitrate in groundwater indicated that three treatment technologies have typically been employed. These technologies are permeable reactive barriers (PRBs), anaerobic bioremediation, and inorganic immobilization.

\subsubsection{Permeable Reactive Barriers}

A PRB consists of a permeable reactive zone installed within the aquifer and oriented perpendicular to groundwater flow for treatment of groundwater contaminants as they flow through the barrier. The reactive zone could be created by different kinds of media, such as organic compounds to enhance anaerobic biological treatment or zerovalent iron to promote chemical reduction.

A PRB using anaerobic bioremediation for treatment can be created by injecting fermentable substrates (i.e., electron donors) to stimulate anaerobic aquifer conditions and degradation or immobilization of contaminants through microbial reduction. The PRB would be created and maintained by periodically injecting large volumes of a dilute solution of electron donor to a line of injection wells spaced to have overlapping zones of influence or radii of injection. The longevity of injectable electron-donor substrates appropriate for PRBs is relatively short (i.e., several months to more than a year) compared to the required period of containment. Donor longevity depends on the mass of the donor injected and the continuing flux of natural electron acceptors (e.g., oxygen) through the PRB.

The PRB can also use chemical media that would either abiotically reduce a contaminant or absorb it. Zerovalent iron is a widely used media at those sites where the COC can be destroyed through chemical reduction. Zerovalent iron is typically deployed as an excavated trench with a mix of sand and iron filings, but it can also be installed through a direct slurry injection. The IX resins have also been tried as PRB media where the contaminant will sorb to the resin (see Section 2.1.1.1 for a description of the IX process).

\subsubsection{Anaerobic Bioremediation}

Anaerobic bioremediation involves the stimulation of anaerobic aquifer conditions and native micro-organisms to degrade or immobilize contaminants through the addition (e.g., injection) of electron-donor substrates into the aquifer. Additionally, anaerobic bioremediation can provide indirect stimulation of beneficial abiotic degradation processes (e.g., anaerobic reduction by iron sulfides).

Biodegradation of contaminants occurs through different reduction/oxidation reactions by which the micro-organisms degrade a contaminant either in an energy-yielding process (metabolic) or without gaining energy (cometabolic or co-oxidation). In metabolic processes, micro-organisms obtain energy by facilitating the transfer of electrons from one compound (electron donor) to another compound (electron acceptor). Cometabolic processes occur as side reactions to other metabolic reactions by which micro-organisms use non-target compounds as the electron acceptor and donor; cometabolic degradation of the contaminant occurs fortuitously with no additional energy gain for the micro-organism.

Metabolic processes for micro-organisms can be compared to human consumption of food (electron donor) and respiration of oxygen (electron acceptor) to obtain energy. A fermentable carbon substrate (e.g., sugar, alcohol, vegetable oil, or petroleum hydrocarbons) can be used by 
micro-organisms as the electron donor. Micro-organisms use electron acceptors, including naturally occurring acceptors (e.g., oxygen, nitrate, manganese, ferric iron, sulfate, or carbon dioxide) and contaminant acceptors (e.g., carbon tetrachloride or TCE). Micro-organisms obtain the greatest energy from the most highly oxidized acceptors and will, therefore, preferentially use and deplete the most oxidized acceptors available. For this reason, oxygen (if present) is the first electron acceptor to be used, followed sequentially by nitrate, manganese (IV), ferric iron $\left(\mathrm{Fe}^{+3}\right)$, sulfate, and carbon dioxide. Aquifer reduction/oxidation conditions (e.g., aerobic, nitrate-reducing, or iron-reducing) are described by the predominant electron acceptor being used by micro-organisms. A contaminant will generally not be degraded through use as an electron acceptor until most of the more highly oxidized natural and contaminant electron acceptors have been depleted (i.e., until the appropriate aquifer reduction/oxidation conditions are established).

Electron donors (i.e., food and nutrients for micro-organisms) that can be injected into the aquifer to stimulate biodegradation include soluble substrates (e.g., sugar, molasses, sodium lactate, cheese whey, and ethanol) and/or insoluble substrates (e.g., vegetable oil and wood mulch) (Principles and Practices of Enhanced Anaerobic Bioremediation of Chlorinated Solvents [Parsons 2004]; Final Technical Protocol for Using Soluble Carbohydrates to Enhance Reductive Dechlorination of Chlorinated Aliphatic Hydrocarbons [Suthersan et al. 2002]). Substrates become fermented and release intermediate fatty acids and the hydrogen electron donor that moves with groundwater flow to establish treatment zones downgradient of injection wells. Achieving the required reducing conditions in the aquifer and the length of time between injections (i.e., days to years) is dependant on the ratio of fast- and slow-release donor substrates in the injected solution. Combined use of soluble and insoluble donor substrates can result in several months to more than a year of longevity (i.e., time between injection events), depending on site-specific factors, such as the mass of natural and contaminant electron acceptors present in the treatment zone and the continuing flux of acceptors through the treatment zone following injection.

For organic contaminants, anaerobic bioremediation can result in dechlorination and destruction of the compound, and for other contaminants such as nitrate, it can result in conversion to a harmless compound (e.g., nitrogen). However, anaerobic bioremediation has also been used for long-term immobilization of inorganic constituents, such as uranium.

\subsubsection{Inorganic Immobilization}

In situ immobilization of radionuclides by a method other than anaerobic bioremediation has also been studied. The other method of immobilization involves groundwater $\mathrm{pH}$ adjustment by injection of high $\mathrm{pH}$ alkaline solutions in order to reduce the mobility of the radionuclides in site groundwater. A case study testing the inorganic immobilization both iodine-129 and uranium is described in the following sections. 


\subsection{NITRATE TREATMENT OPTIONS}

This section describes tested technologies for the treatment of nitrate. In the summary of the literature review provided below, preference has been given to descriptions of technologies that have been tested in the field and secondary preference to technologies that have produced promising laboratory results. The assessments of treatment technology vendors have been included where there is minimal available published data.

\subsection{EX SITU TREATMENT (PUMP-AND-TREAT)}

Due to the high solubility and low partitioning of nitrate into soil, pump-and-treat is likely to be effective in the removal and concentration reduction of nitrate in all zones of groundwater contamination. Both physical/chemical and biological ex situ field tests are described below.

\subsubsection{Physical/Chemical Treatment}

Using IX is a common method to remove nitrates from water ("Pilot-Scale Evaluation of Select Nitrate Removal Technologies" [Darbi et al. 2003]). The method uses a packed bed containing chloride or bicarbonate anions on a strong-base resin that can be regenerated using sodium chloride or sodium bicarbonate.

The use of IX for the removal of nitrate has been documented multiple times, and two examples are as follows:

- In Nitrate and Perchlorate Removal from Groundwater by Ion Exchange (Burge and Halden 1999), a laboratory study showed $80 \%$ removal of nitrate from influent groundwater with a concentration of $100 \mathrm{mg} / \mathrm{L}$ nitrate.

- In "Pilot-Scale Evaluation of Select Nitrate Removal Technologies" (Darbi et al. 2003), a field study demonstrated that approximately $65 \mathrm{mg}-\mathrm{N} / \mathrm{L}$ nitrate could be treated to an average concentration of $6.1 \mathrm{mg}-\mathrm{N} / \mathrm{L}$. The IX system used a strong-base anion-exchange resin.

Remco, ResinTech, Purolite, WRT, and Basin Water are examples of companies providing resins for treatment of nitrate. ResinTech manufactures several nitrate-selective IX products based on higher amine functionalities and also provides standard Type I and Type II strong-base anion resins that can be used for nitrate removal, including their products SIR-100-HP and SGB1-HP (ResinTech 2008). Purolite has a resin named A520E that specifically targets nitrate ${ }^{1}$. Basin Water uses mobile multi-bed systems for the treatment of nitrate, with capacities ranging from 1,136 to $22,712 \mathrm{~L} / \mathrm{min}$ (300 to 6,000 gpm) (Basin Water 2008; "City of Pomona Takes a Forward-Looking Approach to Leveraging Local Water Resources" [Taylor 2005]).

Electrodialysis has been demonstrated to be capable of removing nitrate from groundwater ("Pollution of Nitrate in Moroccan Ground Water: Removal by Electrodialysis" [Elmidaoui et al. 2001]; "Experience with Full-Scale Electrodialysis for Nitrate and Hardness Removal" [Hell et al. 1998]; "Removal of Nitrate by Electrodialysis" [Indusekhar et al. 2001]; "Technical Optimization of Nitrate Removal from Ground Water by Electrodialysis Using a Pilot Plant"

\footnotetext{
${ }^{1}$ Personal communication, e-mail communication re: Iodine, Nitrate, and Uranium Removal Ion-Exchange Technologies, dated February 15, 2008, between P. Roelen (Landau Associates, Edmords, Washington) and S. Soldatek (Western Regional Sales Manager, Purolite Corporation, Berkeley, Califorria).
} 
[Menkouchi Sahli et al. 2004]; "Optimization of Nitrate Operation from Ground Water by Electrodialysis" [Midaoui et al. 2002]). As an example, Hell et al. (1998) used electrodialysis in a full-scale plant $\left(3,500-\mathrm{m}^{3} /\right.$ day flow rate [Ameridia 2008]) to treat up to $120 \mathrm{mg} / \mathrm{L}$ nitrate to a concentration of $20 \mathrm{mg} / \mathrm{L}$.

Reverse osmosis is often referred to as a common technology for the treatment of nitrate using pump-and-treat, although the published number of articles are limited. Fublished literature includes demonstrations of field studies that showed treatment of $65 \mathrm{mg} . \mathrm{N} / \mathrm{L}$ nitrate to an average concentration of $7.7 \mathrm{mg}-\mathrm{N} / \mathrm{L}$ (Darbi et al. 2003), treatment of $42.5 \mathrm{mg} / \mathrm{L}$ of nitrate to $0.9 \mathrm{mg} / \mathrm{L}$ ("Nitrate Removal with Reverse Osmosis in a Rural Area in South Africa" [Schoeman and Steyn 2003]), and treatment to achieve $75 \%$ to $95 \%$ nitrate removal in reverse osmosis plants with 76 and $100 \mathrm{mg} / \mathrm{L}$ nitrate ("Use of Reverse Osmosis for Removal of Nitrate in Drinking Water" [Bilidt 1985]).

Nitrate can also be reduced chemically to ammonia, nitrogen gas, and nitrite. This process would require further treatment to remove the produced ammonia from the water. The only published ex situ study found ("Chemical Removal of Nitrate from Water" [Murphy 1991]) showed that nitrate can be converted to ammonia when reacting with powdered aluminum; however, the reaction required an elevated $\mathrm{pH}$ (no reaction occurred at a $\mathrm{pH}$ of 8). About $60 \%$ to $95 \%$ of the nitrate was converted to ammonia, while the remainder was converted to nitrogen gas and nitrite. Nitrite is very short-lived in anaerobic groundwater and converts quickly to nitrogen gas (Environmental Agency 2005), but the ammonia would require additional treatment.

\subsubsection{Biological}

Bioreactors or constructed wetlands can be used to treat nitrate generated from groundwater extraction. Bioreactors typically consist of process tanks containing media to support biological growth. Bioreactors can also be constructed as an infiltration gallery. Groundwater pumped to the surface from an extraction well would be introduced to a bioreactor together with a carbon source. The mechanisms occurring in the bioreactor would be the same as in situ-enhanced denitrification.

Micro-organisms in a bioreactor would use the carbon source as cell growth substrate and also as an electron donor in a reduction/oxidation reaction with nitrate as the electron acceptor, producing nitrogen gas (as described in Section 2.1.2).

Some of the selected studies are described below for process tank type bioreactors:

- "Biological Nitrate Removal from Water Resources" (Bidhendi et al. 2006) showed in pilot testing that aerobic groundwater with a nitrate concentration of about $75 \mathrm{mg} / \mathrm{L}$ could be treated with up to $88.8 \%$ removal efficiency given a 48 -hour retention time. Approximately $72.9 \%$ removal was seen after only 1 -hour retention time. Acetic acid was used as the carbon source and electron donor.

- Darbi et al. (2003) evaluated a bioreactor set up for nitrate levels in groundwater of $65 \mathrm{mg}-\mathrm{N} / \mathrm{L}$. The system was able to treat the nitrate to an average concentration of $2.4 \mathrm{mg}-\mathrm{N} / \mathrm{L}$ using a hydraulic retention time of 13 hours.

- "Groundwater Denitrification with Alternative Carbon Sources" (Mohseni-Bandpi and Elliott 1998) compared three different electron donors for denitrification using a pilot-scale rotating biological contactor. Influent nitrate concentrations were approximately $40 \mathrm{mg}-\mathrm{N} / \mathrm{L}$, and donors tested were methanol, ethanol, and acetic acid. 
The results indicated that all three functioned as suitable donors, but the highest nitrate removal was achieved with acetic acid (effluent concentration of $0.45 \mathrm{mg}-\mathrm{N} / \mathrm{L}$ compared to $1.7 \mathrm{mg}-\mathrm{N} / \mathrm{L}$ for methanol and $3.3 \mathrm{mg}-\mathrm{N} / \mathrm{L}$ for ethanol). Furthermore, "A Comparison Between Ethanol and Methanol as Carbon Sources for Identification" (Christensson et al. 1994) indicated in a laboratory study that ethanol was a more efficient electron donor than methanol. The growth rate of denitrifiers was two to three times greater with ethanol compared to methanol.

- Applied Process Technology is a company that is trying to commercialize their membrane biofilm reactor technology that is specifically designed to chemically and biologically reduce nitrate. Hydrogen diffuses through a membrane and acts as an electron donor, building up a biofilm on the membrane. The biofilm, consisting of autotrophic micro-organisms, then degrades nitrate to nitrogen gas. This technology has been tested in the laboratory for nitrate and perchlorate and has been shown to treat nitrate at 120 parts per million (ppm) down to below 0.2 ppm ("Simultaneous BioReduction of Nitrate, Perchlorate, Selenate, Chromate, Arsenate, and Dibromochloropropane Using a Hydrogen-Based Membrane Biofilm Reactor" [Chung et al. 2007]; "Reduction of Perchlorate and Nitrate in Groundwater Using a Hollow-Fiber Membrane Biofilm Reactor (MBfR)" [Bowman 2005]).

Permeable mulch bio-barriers have been demonstrated in pilot-scale and full-scale applications to provide successful biological treatment of chlorinated solvent and perchlorate groundwater plumes at a number of U.S. Air Force installations ("Biological PRB Application Expanded to Accelerate Perchlorate Degradation in Ground Water" [EPA 2006]; "Biological PRB Used for Perchlorate Degradation in Ground Water" [EPA 2004]; Permeable Reactive Barriers: Leasons Learned/New Directions -- Technical/Regulatory Guidelines [ITRC 2005]; "Performance Validation of a Mulch Biowall for Remediation of Chlorinated Ethenes" [Henry et al. 2004]). This same approach has been applied to the treatment of extracted groundwater containing TCE through construction of a horizontal layer of mulch within an infiltration gallery (Short CourseEnhanced Anaerobic Bioremediation Using Permeable Mulch Biowalls [Wilson et al. 2007]). This infiltration gallery approach is termed a "mulch bioreactor." Extracted groundwater is treated as it infiltrates through the mulch layer, and infiltrating groundwater carries dissolved organic carbon below the mulch layer to stimulate biological treatment of deeper contamination. Biological treatment of perchlorate and TCE requires aquifer reduction/oxidation conditions that are the same or more reducing than those required for the biological treatment of nitrate.

Constructed wetlands case studies include the following:

- A constructed wetland was used to remove nitrate from the municipal drinking water supply in Orange County, California ("Nitrate Removal from a Drinking Water Supply with Large Free-Surface Constructed Wetlands Prior to Groundwater Recharge" [Reilly et al. 1999]). The source water was the effluent-dominated Santa Ana River and up to $1.5 \mathrm{~m}^{3} / \mathrm{sec}$ ( 33 million gal/day) were treated prior to groundwater recharge. The influent contained 3.1 to $10.9 \mathrm{mg} / \mathrm{L} \mathrm{NO}_{3}-\mathrm{N}$. The average nitrate removal was $522 \mathrm{mg} \mathrm{NO}-\mathrm{N}$ per square meter per day, and exiting nitrate concentrations sometimes fell to as low as $0.1 \mathrm{mg} / \mathrm{L} \mathrm{NO}_{3}-\mathrm{N}$, with hydraulic detention times from 0.3 to 9.6 days. Average efficiency for the entire wetland was $79 \%$ (range of $14 \%$ to $100 \%$ ), and bacterial denitrification was concluded to be the primary nitrate loss mechanism. 
- In a review of 19 surface flow wetlands (Design Manual: constructed Wetlands and Aquatic Plant Systems for Municipal Wastewater Treatment [EPA/625/1-88/022]), it was observed that nearly all reduced total nitrogen.

- A review of both surface flow and subsurface flow wetlands ("Subsurface Flow Wetlands" [Reed 1995]) concluded that effluent nitrate concentration depends on maintaining anoxic conditions so denitrification can occur. It was found that subsurface flow wetlands outperformed surface flow wetlands for nitrate removal. The 20 surface flow wetlands reviewed reported effluent nitrate levels below $5 \mathrm{mg} / \mathrm{L}$; the 12 subsurface flow wetlands reviewed reported effluent nitrate ranging from $<1$ to $<10 \mathrm{mg} / \mathrm{L}$.

- Two flow-through pilot-scale constructed wetlands were constructed ("Nitrate Removal from Groundwater Using Constructed Wetlands Under Various Hydraulic Loading Rates" [Lin et al. 2008]) with the same size but various flow patterns (free-water surface flow and subsurface flow) to receive a nitrate-contaminated groundwater. Nitrate removal rates of both wetlands increased with increasing hydraulic loading rate until a maximum value was reached. After the maximum values were reached, further increasing the hydraulic loading rate led to a considerable decrease in nitrate removal rate. Nitrate removal efficiencies remained high ( $>85 \%)$, and effluent nitrate concentrations always satisfied the DWS $(<10 \mathrm{mg} / \mathrm{L})$ within a certain hydraulic loading rate for both free-water surface flow and subsurface flow wetlands.

- "Using a Wetland Bioreactor to Remediate Ground Water Contaminated Nitrate $(\mathrm{mg} / \mathrm{L})$ and Perchlorate $(\mu \mathrm{g} / \mathrm{L})$ " (Krauter 2001) created a pilot wetland bioreactor using indigenous plants to treat nitrate and perchlorate in groundwater. The system was able to treat $80 \mathrm{mg} / \mathrm{L}$ nitrate to $<4 \mathrm{mg} / \mathrm{L}$ with a retention time of 1 day. The addition of additional carbon had no significant impact on nitrate degradation.

- A constructed wetland in Thailand with the size of $29,920 \mathrm{~m}^{2}(18.6 \mathrm{mi})$ was built with the purpose of tertiary treatment of wastewater. The wetland was able to remove nitrate with an efficiency of 52\% (Yirong and Puetpaiboon 2004).

- In a laboratory study, "Ammonium and Nitrate Removal in Vegetated and Unvegetated Gravel Bed Micocosms Wetlands" (Zhu and Sikora 1995) showed that the vegetation had great impact on the treatment efficiency. Without the addition of carbon, only $14 \%$ to $30 \%$ nitrate was degraded using bulrush, reed, and typha. In contrast, about $55 \%$ to $70 \%$ nitrate was removed when using canary grass. The study indicated that the difference had to do with the amount of carbon released from canary grass roots (15 to $20 \mathrm{mg} / \mathrm{L}$ ).

Constructed wetlands can potentially act as a means to remove nitrate from groundwater or brine from treated groundwater. The process would be the similar for use in wastewater treatment, with the difference being that groundwater would be pumped through it (or the waste product from a pump-and-treat system).

\subsection{IN SITU TREATMENT-}

Both PRBs and anaerobic bioremediation have been studied for the treatment of nitrate in groundwater, as summarized below. 


\subsubsection{Permeable Reactive Barriers}

The use of PRBs can efficiently treat nitrate. A limited number of studies have been published where the targeted compound has been nitrate. However, PRBs have been used at several chlorinated compound sites. When chlorinated compounds have been targeted at a site that contains nitrate, the nitrate is reduced in the reductive treatment process (Parsons 2004) (e.g., nitrate is more oxidized than, for example, TCE, and is preferentially reduced compared to TCE).

Some field applications using biological treatment PRBs directly targeting nitrate, are described below:

- Performance Evaluation of a Carbon-Based Reactive Barrier for Nitrate Remediation [Wilkin et al. 2006]) used a PRB for 4 years that was made of wheat-straw to treat nitrate ${ }^{1}$. About $92 \%$ to $100 \%$ removal of nitrate was seen in the wall, and average concentration decreases between influent and effluent concentrations ranged from $42 \%$ to $91 \%$, depending on location. Influent water contained nitrate up to levels as high as $80 \mathrm{mg}-\mathrm{N} / \mathrm{L}$, and effluent levels in downgradient wells in line with the middle of the PRB decreased to nondetection.

- At a site in Japan, biodegradable plastics were used together with iron powder to stimulate denitrification. After 4 months, groundwater influent with concentrations of $10 \mathrm{mg}-\mathrm{N} / \mathrm{L}$ was treated in the barrier to zero ("In Situ Denitrification of NitrateContaminated Groundwater by Permeable Reactive Barrier" [Takamichi et al. 2002]).

- "Nitrate Removal from Groundwater Using a Denitrification Wall Amended with Sawdust: Field Trial" (Schipper and Vojvodić-Vuković 1998) used a 1.5-m (16.4-ft)-wide PRB made out of sawdust mixed with soil. The permeable wall was able to treat 6.9 to $13.3 \mathrm{mg}-\mathrm{N} / \mathrm{L}$ to concentrations to below $1 \mathrm{mg}-\mathrm{N} / \mathrm{L}$.

No published data on the use of mulch barriers for treatment of nitrate were found, but mulch barriers have been used several times for treatment of chlorinated solvents by creating strongly reducing conditions (2007 AFCEE Workshop on Enhanced In Situ Bioremediation [AFCEE 2007]). In previous evaluations, it was found that a mulch barrier can be installed for approximately one-quarter to one-third of the cost of a zerovalent iron wall (AFCEE 2007) and would be worth further evaluation and consideration if there were compelling reasons to install a PRB at the site versus using other remedial technologies.

\subsubsection{Anaerobic Bioremediation}

Enhanced in situ bioremediation to treat nitrate is common, and several studies have been published. Since nitrate is very oxidized (only oxygen is generally more oxidized in uncontaminated groundwater), it can easily be reduced through biodenitrification.

Biodenitrification occurs through microbially mediated reactions whereby micro-organisms obtain energy by reduction/oxidation reactions. Nitrate is anaerobically reduced to nitrogen gas as shown below:

$$
\mathrm{NO}_{3}>\mathrm{NO}_{2}->\mathrm{NO}(\mathrm{g})->\mathrm{N}_{2} \mathrm{O}>\mathrm{N}_{2}(\mathrm{~g})
$$

\footnotetext{
${ }^{1}$ Personal communication, e-mail communication re: PRB Applications for Nitrate Removal, dated February 21, 2008, between B. Jonsson (Landau Associates, Edmonds, Washington) and R. Wilkin (U.S. Environmental Protection Agency, National Risk Management Laboratory, Washington, D.C.).
} 
The denitrification process can occur through either autotrophic or heterotrophic micro-organisms. Autotrophic micro-organisms use inorganic carbon $\left(\mathrm{CO}_{2}\right.$ and $\left.\mathrm{HCO}_{3}{ }^{-}\right)$for cell synthesis and inorganic compounds (e.g., hydrogen or sulfur) as an energy source, using it as an electron donor. Heterotrophic micro-organisms use organic carbon for both cell synthesis and energy source and are the most common denitrifiers. The degradation processes occur through reduction/oxidation reactions (as described in Section 2.2.2). Denitrification can be enhanced by the addition of electron donor (i.e., a carbon source that can either be used directly by heterotrophic denitrifiers or fermented to hydrogen, which can be used by autotrophic denitrifiers).

Several field and laboratory treatment studies have been performed using bioremediation to remove nitrate, such as follows:

- "Ethanol-Stimulated Bioremediation of Nitrate-Contaminated Ground Water" (Tartakovsky et al. 2002) involved injecting ethanol as a carbon source to stimulate denitrification and demonstrated nitrate removal rates up to $1.4 \mathrm{mg}-\mathrm{N} / \mathrm{L} /$ day in the field at a site when nitrate levels were greater than $25 \mathrm{mg}-\mathrm{N} / \mathrm{L}$. Nitrate levels below $10 \mathrm{mg}-\mathrm{N} / \mathrm{L}$ were seen in observation wells after 20 days from injection start and below $5 \mathrm{mg}-\mathrm{N} / \mathrm{L}$ after the study was ended about 150 days after injection.

- "Pilot-Scale Field Test Results of Enhanced In Situ Denitrification" (Lathrop et al. 2003) demonstrated a $40 \%$ to $50 \%$ reduction of nitrate after injection of Hydrogen Release Compound (HRC ${ }^{3}$ ) as a carbon source. The area for the pilot test contained levels of nitrate between 70 and $320 \mathrm{mg} / \mathrm{L}$.

- Sodium acetate was added in a pilot test at a New Mexico site in Albuquerque's South Valley, which stimulated denitrification. It decreased nitrate concentrations from $100 \mathrm{mg}-\mathrm{N} / \mathrm{L}$ to less than $1 \mathrm{mg}-\mathrm{N} / \mathrm{L}$ (Emerging Technologies for Enhanced In Situ Biodenitrification (EISBD) of Nitrate-Contaminated Ground Water [ITRC 2000]).

- At a site in Nebraska with average nitrate concentrations of $40 \mathrm{mg}-\mathrm{N} / \mathrm{L}$, denitrification was stimulated by the addition of ethanol. Complete denitrification was seen downgradient of the injection location (ITRC 2000).

- There are numerous chlorinated-compound and petroleum-contaminated sites where enhanced bioremediation has taken place to degrade contaminants. At these sites where nitrate is present, denitrification will be enhanced as well and will degrade nitrate at the same time or prior to the targeted contaminant. "In Situ Reductive Dechlorination of Chlorinated Ethenes in High Nitrate Groundwater" (Bennett et al. 2007) showed that in a pilot test for treatment of chloroethenes, levels of nitrate $(>230 \mathrm{mg} / \mathrm{L})$ were degraded to nondetect from stimulation using sucrose or dextrose/fructose.

Enhanced in situ biodenitrification would target nitrate and compounds that are more oxidized than, or as oxidized as, nitrate. At an aerobic site such as the 200 West Area at Hanford, injection of an electron donor would first be used to degrade oxygen and then nitrate.

Since fermentive micro-organisms and denitrifiers are widespread, several electron donors can be used as energy and carbon sources. The choice of the specific electron donor is influenced by whether a slow-release and long-lasting electron donor or a fast-release and short-lived electron donor is desired.

$\mathrm{HRC}^{\circledast}$ is a registered trademark of Regenesis, San Clemente, California. 


\subsection{IODINE-129 TREATMENT OPTIONS}

Published studies that address the treatment of iodine-129 in groundwater are extremely limited, and no vendors approached have had any significant experience with treating iodine-129. Some limited published data were identified for ex situ treatment of iodine or iodide, and one literature case study identified where the in situ stabilization of iodine was tested. In addition, based on the known chemical properties of iodine-129 and based on discussion with treatment technology vendors, some well-developed and documented technologies are discussed in this section as having estimated effectiveness for treating iodine-129 in Hanford Site groundwater.

\subsection{EX SITU TREATMENT (PUMP-AND-TREAT)}

For ex situ treatment of iodine-129, there were no identified literature citations for biological treatment. However, published documents were found indicating potential successful treatment of iodine-129 using physical/chemical treatment methods.

\subsubsection{Physical/Chemical Treatment}

Literature review findings for the treatment of iodine-129 by IX, GAC, electrodialysis, and reverse osmosis are described below.

\subsubsection{Ion Exchange. Laboratory Evaluation of I-129 and Tc-99 Removal at the F-Area} Water Treatment Units (Serkiz and Kanzleiter 2002) showed in a laboratory study that iodine-129 can be effectively removed through use of the commercial strong-base anionexchange resin SIR-1200. The resin was found to be able to remove iodine-129 from water to below laboratory detection limits. The Handbook of Ion Exchange Resins - Their Application to Inorganic Analytical Chemistry (Korkisch 1989) also lists iodide as a compound that can be removed.

In addition to limited published literature, several treatment technology vendors claim that their resins will work for removal of iodine-129. Remco, ResinTech, and Purolite indicate in their product descriptions that they have strong-base anion-exchange resins that will work to remove iodide (Remco $2008^{1}$; Purolite 2008). ResinTech, for example, has a resin that specifically targets monovalent ions that they claim would work for iodide (ResinTech 2008). ResinTech is also the supplier of the SIR-1200 for the study discussed above (WSRC-TR-2002-00435). Purolite indicated that they have a resin that they believe would work (A600), but they have not performed significant testing on iodide ${ }^{2}$.

4.1.1.2 Granular Activated Carbon. GAC has been shown to be effective in removing iodine $\left(\mathrm{I}_{2}\right)$ from wastewater or groundwater. However, it has not been documented and it is not expected based on chemical differences that unaltered GAC would be effective in removing iodide (I), which is the expected form of iodine-129 in groundwater. What has been shown to be effective in removal of iodide is silver-impregnated activated carbon (SIAC). SIAC was

\footnotetext{
${ }^{1}$ Personal communication, e-mail communication re: Iodine Removal Ion-Exchange Technologies, dated February 21, 2008, between B. Jonsson (Landau Associates, Edmonds, Washington) and R. E. Mesick (Remco Engineering, Ventura, California).

${ }^{2}$ Personal communication, e-mail communication re: Iodine, Nitrate, and Uranium Removal Ion-Exchange Technologies, dated February 15, 2008, between P. Roelen (Landau Associates, Edmonds, Washington) and S. Soldatek (Western Regional Sales Manager, Purolite Corporation, Berkeley, California).
} 
developed through work by the Savannah River Technology Center and Clemson University and was shown in a laboratory study to effectively remove iodine-129 (WSR.C-TR-2002-00571). The SIAC was found to be able to remove iodine- 129 from water to below laboratory detection limits.

4.1.1.3 Electrodialysis. No published literature was identified that evaluated the use of electrodialysis for treatment of iodine-129 or iodide. Based on the chemical properties of iodine-129 in groundwater, it is expected that electrodialysis could be used to remove iodine-129. It is expected that the cost would be relatively high, but the specific cost and effectiveness of this technology cannot be estimated due to the lack of available data.

4.1.1.4 Reverse Osmosis. Similar to electrodialysis, no published literature was identified that evaluated the use of electrodialysis for treatment of iodine-129 or iodide, but it is expected that reverse osmosis could be used to adequately remove iodine- 129 based on general principles of the technology. It is expected that the cost of reverse osmosis would be relatively high, but the specific cost and effectiveness of this technology cannot be estimated due to the lack of available data.

\subsection{IN SITU TREATMENT}

One case study was identified on the immobilization of contaminants at a site that included iodine-129 among its primary contaminants. This technology study was performed by the U.S. Department of Energy's (DOE's) Savannah River National Laboratory at the Savannah River Site in South Carolina and involved a $1-\mathrm{km}^{2}\left(0.39-\mathrm{mi}^{2}\right)$ metals and radionuclides waste site known as the "F-Area seepage basins," where a modified funnel and gate barrier system has operated since 2005 to treat groundwater containing strontium-90, uranium isotopes, iodine-129, technetium-99, and tritium ("SNRL Evaluates Sustainable Remediation Strategies for Metals and Radionuclides" [EPA 2008]). The groundwater at the site is acidic ( $\mathrm{pH}$ between 3.2 and 4.0), which increases the mobility of certain site contaminants. The immobilization testing has involved periodic injection of alkaline solutions of $\mathrm{pH} 10$ into the gates to neutralize groundwater and reduce mobility of some contaminants. The alkaline-enhanced funnel and gate system treats all of the contaminants by mixing the stratified plume at the barrier wall, as well as pH-sensitive contaminants such as strontium-90 and uranium isotopes at the gates. The frequency of injection has been determined through downgradient measurement of groundwater $\mathrm{pH}$. In 3 years of operation, injections were required at 12-month intervals at one gate and 18-month intervals at the second gate. Savannah River National Laboratory indicates that the immobilization treatment strategy is more sustainable and less costly than the pump-and-treat system that cost approximately $\$ 1$ million per month and produced a significant quantity of solid radioactive waste requiring disposal. 
SGW-37783, Rev. 0

\subsection{URANIUM TREATMENT OPTIONS}

This section describes tested technologies for the treatment of uranium. In the summary of the literature review provided below, preference has been given to descriptions of technologies that have been tested in the field and secondary preference to technologies that have produced promising laboratory results. The assessments of treatment technology vendors have been included where there is minimal available published data.

\subsection{EX SITU TREATMENT}

Limited published literature was identified for ex situ treatment of uranium. The identified physical/chemical treatment and biological treatment technologies are discussed below.

\subsubsection{Physical/Chemical Treatment}

There are not many published articles about treating uranium (VI) using physical/chemical treatment methods, although it is considered a common technology (Ion Exchange Technology: Advances in Environmental Pollution Control [Sengupta 1995]) and many vendors claim they can treat uranium (VI). According to Remco, both reverse osmosis and IX are very efficient methods for treating uranium-rich water (Remco 2008). ResinTech states that two of their IX products (SBG1-HP and SIR-1200) specifically target uranium. SIR-1200 is also the product that was used in the WSRC-TR-2002-00435 study to remove iodine-129 (see Section 4.1.1.1). Purolite provides at least three resins with the capability to remove uranium, and at least one also targets nitrate (Purolite 2008). WRT provides a treatment sorption option where the uraniumcontaminated water is passed through a fluidized bed with adsorptive media, and they claim that their method has been able to treat water contaminated with $370 \mu \mathrm{g} / \mathrm{L}$ to below $30 \mu \mathrm{g} / \mathrm{L}$ (WRT 2008). In a pilot study, the system was able to treat contaminated groundwater with average uranium concentrations of $271.8 \mu \mathrm{g} / \mathrm{L}$ down to $1.2 \mu \mathrm{g} / \mathrm{L}$ (WRT 2008).

Furthermore, electrodialysis was used in a field study to remove uranium from groundwater (Sengupta 1995). The study indicated greater than $95 \%$ removal of $120 \mu \mathrm{g} / \mathrm{L}$ contaminated water, but most of the uranium ( $83 \%$ ) had accumulated in the anion-exchange membranes rather than ending up in the brine (Sengupta 1995). Reverse osmosis s another demonstrated technology that has been shown to reduce uranium. Sengupta (1995) describes a case study where $99 \%$ treatment was achieved with spiked groundwater with $300 \mu \mathrm{g} / \mathrm{L}$ uranium using reverse osmosis.

\subsubsection{Biological Treatment}

The use of a constructed wetland or irrigation field is a potential treatment remedy for uranium. Rhizofiltration is a phytoremediation process where roots of plants absorb a contaminant from groundwater and accumulate it. The plants, including the roots that contain the contaminant, can then be harvested and properly disposed. "Removal of Uranium from Water Using Terrestrial Plants" (Dushenkov et al. 1997) used certain sunflower plants in a field and laboratory test to remove uranium from groundwater. The plants in the field were able to reduce concentrations ranging from 21 to $874 \mu \mathrm{g} / \mathrm{L}$ to less than $20 \mu \mathrm{g} / \mathrm{L}$. Even when the groundwater influent was spiked to achieve a concentration of above $1,000 \mu \mathrm{g} / \mathrm{L}, 95 \%$ was removed. About $99 \%$ of the uranium removed in the laboratory was found in the roots, and although the study mentions that $>1 \%$ uranium was found in the roots of the plants in the field, it is not clear how much above 
$1 \%$ was accumulated. If it was much less than in the laboratory, the article does not describe its fate.

Phytoremediation could be an option to further investigate for the use of removing uranium from groundwater at the 200 West Area. Although no commercial applications were found, it might be a promising alternative; however, a pilot test is needed to be performed and evaluated to understand the removal mechanisms onsite. It is crucial that the uranium is actually removed (i.e., accumulated in the roots of the plants) and not just reduced to uranium (IV) by micro-organisms that are stimulated by the nutrients in the roots (i.e., phytostimulation). If uranium is simply being reduced, is it likely that it can be reoxidized and resolubilized after removal of the plants by oxygen and nitrate present in the groundwater, as previously described in for in situ enhanced bioremediation.

\subsection{IN SITU TREATMENT}

The in situ treatment technologies identified in the published literature for uranium were anaerobic bioremediation, PRBs, and immobilization.

\subsubsection{Anaerobic Bioremediation}

Uranium is mobile under oxic (i.e., aerobic) conditions but is immobile under iron-reducing conditions, which can be created through anaerobic bioremediation (sometimes referred to in the literature as "biostimulation"). A number of articles have been published regarding biological treatment of uranium (i.e., reducing it from oxidation state 7 to 4); however, the possibility for reoxidation and remobilization is a concern.

Uranium (VI) can be biologically reduced to uranium (IV) and become immobile. The mechanism for biodegradation was previously discussed in Section 2.2.2. Uranium (VI) is an oxidized compound, but oxygen and nitrate are more oxidized and will be reduced first ("Biological Reduction of Uranium in Groundwater and Subsurface Soil" [Abdelouas et al. 2000]). Uranium (VI) can be reduced under iron- or manganese-reducing conditions (Abdelouas et al. 2000; "Change in Bacterial Community Structure During In Situ Biostimulation of Subsurface Sediment Co-Contaminated with Uranium and Nitrate" [North et al 2004]).

Some of the field studies have included the following:

- "In Situ Bioreduction of Technetium and Uranium in a Nitrate-Contaminated Aquifer" (Istok et al. 2004) indicated in a series of groundwater well push-pull tests that uranium (VI) could be reduced under iron-reducing conditions in the presence of nitrate $(120 \mathrm{nM})$. After nitrate was removed through addition of ethanol, glucose, and acetate, uranium (VI) was reduced to uranium (IV). Their results also inferred reoxidation of uranium (IV) through addition of nitrate.

- "In-Situ Evidence for Uranium Immobilization and Remobilization" (Senko et al. 2002) showed in push-pull tests that $1.5 \mu \mathrm{M}$ uranium (VI) could be reduced to only $0.5 \mathrm{nM}$ through enhanced biodegradation using lactate, acetate, and formate as electron donors. The study also showed that uranium (IV) could be reoxidized by nitrate to uranium (VI).

- Abdelouas et al. (2000) showed in a laboratory study that uraniurn (VI) could be reduced to uraninite $\left(\mathrm{UO}_{2}\right)$. They also indicated that produced iron sulfides during stimulation could act as a buffer for reoxidation of uranium. 
- "Stimulating the In Situ Activity of Geobacter Species to Remove Uranium from the Groundwater of a Uranium-Contaminated Aquifer" (Anderson et al. 2003) used biostimulation to treat uranium (VI) in a fairly large field experiment. Using 20 injection wells oriented perpendicular to the groundwater flow, they injected acetate (1 to $3 \mathrm{mM}$ ) to treat groundwater with uranium (VI) concentrations of 0.4 to $1.4 \mu \mathrm{M}$. Biodegradation, occurring simultaneously with iron reduction, decreased concentrations to lower than $0.18 \mu \mathrm{M}$, and might be associated with Geobacter micro-organisms. The reduction of uranium (VI) decreased when the reduction-oxidation conditions changed to sulfatereducing, which might indicate that the reduction of uranium (VI) is a cometabolic process (i.e., the micro-organism cannot gain energy from the reaction).

- "Pilot-Scale In Situ Bioremediation of Uranium in a Highly Contaminated Aquifer" (Wu et al. 2006) involved a pilot test to treat uranium in groundwater at a site with 80 to $160 \mathrm{mM}$ nitrate. Ethanol was added in a recirculation system, which first enhanced denitrification followed by uranium (VI) reduction (5 to $1 \mu \mathrm{M}$ ), and then uranium (VI) reduction combined with sulfate reduction, indicating that reduction can take place under sulfate-reducing conditions. Abdelouas et al. (2000) also showed that uranium (VI) reduction occurred under sulfate-reducing conditions.

Some studies have shown that anaerobic biostimulation is a very promising technology for reducing and immobilizing uranium under certain conditions. However, immobilization of uranium is not technically implementable in naturally aerobic aquifers (e.g., 200 West Area unconfined aquifer). Although anaerobic conditions can be induced in the aerobic aquifer and uranium precipitated, the reduced uranium will resolubilize as oxic or nitrate-reducing conditions are re-established. In one study, $88 \%$ and $97 \%$ of biologically reduced uranium was reoxidized by oxygen and nitrate, respectively ("Uranium Reoxidation in Previously Bioreduced Sediment by Dissolved Oxygen and Nitrate" [Moon et al. 2007]). Although anaerobic aquifer conditions could be temporarily induced in the 200 West Area unconfined aquifer, it is estimated that aerobic conditions would be reestablished following treatment and uranium would be remobilized.

\subsubsection{Permeable Reactive Barriers}

The PRB technology has been used to immobilize uranium. Different applications of PRBs have been used to reduce uranium (VI) to uranium (IV) through microbial stimulation to sequester the uranium in an immobile form, or PRB materials have been used to adsorb uranium to material in the wall.

- The Cost and Performance Report - In Situ Permeable Reactive Barriers for Contaminated Groundwater at Fry Canyon, Southeastern Utah [EPA 2000]) discusses the testing of three PRBs to treat uranium contaminated groundwater (up to $16 \mathrm{mg} / \mathrm{L}$ ) with three different media: phosphate, zerovalent iron, and amorphous ferric oxyhydroxide (AFO). The best performance was achieved by the zerovalent iron barrier that removed $99.9 \%$ of uranium (VI) immediately after installation and consistently during the first year of operation. The phosphate barrier removal efficiency fluctuated between $62 \%$ and $99.9 \%$ and the AFO between $37 \%$ and $95 \%$. 
- The Federal Remediation Technology Roundtable (Evaluation of Permeable Reactive Barrier Performance [FRTR 2002]) discusses two DOE sites where iron filled barriers were efficiently used to treat uranium (Y-12 Plant in Tennessee, and the Mill Tailings Site in Utah).

- There are many options to regarding what type of media to use in a barrier. "Performance of Three Resin Based Materials for Treating Uranium Contaminated Groundwater Within a PRB" (Barton et al. 2004) tested three IX resins in column tests to mimic behavior in PRBs with promising results. Another option, likely cheaper, would be to use a mulch barrier as described in the section previously for PRBs used for treatment of nitrate.

The use of a PRB to reduce uranium (VI) would likely not be effective in Hanford's 200 West Area. Although biotreatment in the PRB could result in reduction and immobilization of uranium, significant resolubilization would occur as the naturally aerobic aquifer conditions become re-established, as described previously for in situ anaerobic bioremediation.

\subsubsection{Immobilization}

As described in Section 4.2 for iodine-129, a case study was performed of the immobilization of contaminants at a site that included iodine- 129 and uranium among its primary contaminants. This technology study was performed by DOE's Savannah River National Laboratory at the Savannah River Site and involved a $1-\mathrm{km}^{2}\left(0.39 \mathrm{mi}^{2}\right)$ metals and radionuclides waste site known as the "F-Area seepage basins," where a modified funnel and gate barrier system has operated since 2005 to treat groundwater containing strontium-90, uranium isotopes, iodine-129, technetium-99, and tritium (EPA 2008). The immobilization testing has involved periodic injection of alkaline solutions of $\mathrm{pH} 10$ into the gates to neutralize groundwater and reduce mobility of some contaminants. The alkaline-enhanced funnel and gate system treats all contaminants by mixing the stratified plume at the barrier wall as well as $\mathrm{pH}$-sensitive contaminants such as strontium- 90 and uranium isotopes at the gates. In addition to the discussion in Section 4.2, Savannah River National Laboratory states that early analytical data from downgradient wells indicate the system effectively reduces concentrations of uranium isotopes to below the DWS. 
SGW-37783, Rev. 0

\subsection{CONCLUSIONS}

Based on the information gathered from the review of published literature and from discussions with technology vendors, some general conclusions can be drawn as to which treatment technologies could be considered as applicable for further consideration at the Hanford Site for the COPCs nitrate, iodine-129, and uranium.

\subsection{APPLICABLE NITRATE TREATMENT TECHNOLOGIES}

The nitrate treatment technologies that are considered to be applicable for further consideration at the 200-ZP-1 OU of the Hanford Site are pump-and-treat, PRBs, and in situ anaerobic bioremediation.

Of the two in situ technologies identified for nitrate, anaerobic bioremediation may be more easily implemented than a PRB considering the significant depth below ground surface of impacted groundwater at the Site. An anaerobic bioremediation remedy could be accomplished with injection wells, whereas successful installation of a PRB without gaps in the treatment zone becomes significantly more challenging and costly with increasing depth.

With a pump-and-treat remedy, the physical/chemical treatment technologies considered to be applicable for nitrate removal are IX, electrodialysis, and reverse osmosis. Based on review of vendor literature and documentation, IX appears to be a relatively more implementable and cost-effective ex situ treatment option for the Hanford Site because it would not generate a large-volume concentrated liquid waste stream that would require further handling and treatment. A number of companies and vendors produce strong-base anion-exchange resins with documented success in removing nitrate from water. With the provision of specific groundwater chemistry data and treatment goals (e.g., flow rates and durations) to the IX vendors, specific resins could be recommended for the Site, and comparisons of effectiveness and cost could be made for selecting specific alternatives. Ultimately, laboratory or bench-scale tests with Site groundwater would likely be required to ensure that relevant treatment goals could be achieved.

With a pump-and-treat remedy, the biological treatment technologies considered to be applicable for nitrate removal are use of a bioreactor (including a mulch bioreactor) or a constructed wetland. Of these two biological treatment options, there is no immediate clear preference from the literature based on implementability, cost, or effectiveness.

\subsection{APPLICABLE IODINE-129 TREATMENT TECHNOLOGIES}

The treatment technologies that were identified for iodine-129 to be applicable for further consideration were mostly limited to pump-and-treat remedies. One case study was identified that evaluated in situ immobilization of contaminants in groundwater, including iodine-129. However, the data available from that case study were limited and the strongly acidic groundwater conditions at that site were different than the 200-ZP-1 OU, so it cannot be concluded that an immobilization approach would be appropriate for the Hanford Site.

With a pump-and-treat remedy, the treatment methods considered to be applicable for iodine-129 removal are IX, SIAC, electrodialysis, and reverse osmosis.

Although very limited published literature was found for any treatment methods for iodine-129, based on vendor information and known removal rates of compounds with similar chemical 
characteristics, IX may be the most cost-effective treatment option for iodine-129 removal. The literature suggests that strong-base anion-exchange resins can have strong affinities toward the removal of iodide $\left(\mathrm{I}^{-}\right)$, which is an iodine species that exists under most normal groundwater conditions. Assuming that iodine-129 speciates in the same manner as naturally occurring iodine (which is suggested in certain literature), strong-base anion-exchange resins should be effective in removing iodine-129 in the iodide form, and likely in the iodate (IO3) form (also a negatively charged ion).

The IX resins are designed to be selective for removal of certain types of compounds, but it may be determined that other similar compounds or contaminants present in 200-ZP-1 groundwater compete for adsorption sites, cause premature breakthrough of the resin, and cause IX to be ineffective in removing iodine-129. Therefore, bench-scale or pilot-scale testing with Hanford Site groundwater would be necessary to verify whether IX would be effective for iodine-129 at the 200-ZP-1 OU.

\subsection{APPLICABLE URANIUM TREATMENT TECHNOLOGIES}

The treatment technologies that were identified to be applicable for further consideration for uranium in groundwater were limited to pump-and-treat remedies.

Although multiple studies have discussed in situ anaerobic bioremediation for the reduction of uranium (VI) in groundwater to the less mobile form of uranium (IV), this approach is considered unlikely to be an effective long-term remedy for 200-ZP-1 groundwater because the naturally aerobic aquifer conditions would return after treatment and allow reoxidation by oxygen or nitrate back to mobile uranium (VI). Use of a PRB to reduce and immobilize uranium would be expected to have the same problem over time. Therefore, in situ treatment remedies for uranium do not appear to be appropriate options for the Hanford Site.

For a pump-and-treat remedy, it may be possible to use a constructed wetland or irrigation field for phytoremediation for the removal of uranium from extracted groundwater. However, given the limited amount of field testing data that were identified and because the removal mechanisms are not fully understood, it cannot yet be considered a reliable remedial technology for uranium.

With a pump-and-treat remedy, the physical/chemical treatment technologies considered to be applicable for nitrate removal are IX or a membrane separation technology (i.e., electrodialysis or reverse osmosis). Based on a review of literature and vendor communications, IX appears to be a relatively more implementable and cost-effective ex situ treatment option for the Hanford Site because it would not generate a large-volume concentrated liquid waste stream that would require further handling and treatment. A number of companies and vendors produce strongbase anion-exchange resins with documented success in removing uranium from water and could assist with bench-scale testing of groundwater from the 200-ZP-1 OU. 


\subsection{REFERENCES}

Abdelouas, A., W. Lutze, W. Gong, E. H. Nuttall, B. A. Strietelmeier, and B. J. Travis, 2000, "Biological Reduction of Uranium in Groundwater and Subsurface Soil," in Science of the Total Environment, 250(1-3):21-35.

AFCEE, 2007, 2007 AFCEE Workshop on Enhanced In situ Bioremediation, Air Force Center for Engineering and the Environment, School of Aerospace Medicine, Brooks City-Base, Texas, April 24-25, 2007 (http://www.afcee.brooks.af.mil/products/techtrans/ workshop/eisb2007/).

Ameridia, 2008, http://www.ameridia.com/html/pw.html, Ameridia, Somerset, New Jersey.

Anderson, R. T., H. A. Vrionis, I. Ortiz-Bernad, C. T. Resch, P. E. Long, R. Dayvault, K. Karp, S. Marutzky, D. R. Metzler, A. Peacock, D. C. White, M. Lowe, and D. R. Lovley, 2003, "Stimulating the In Situ Activity of Geobacter Species to Remove Uranium from the Groundwater of a Uranium-Contaminated Aquifer," in Applied and Environmental Microbiology, 69:5884-5891.

ANL, 2005, EVS Human Health Fact Sheet, dated August 2005, Argonne National Laboratory, Argonne, Illinois.

Barton, C. S., D. I. Stewart, K. Morris, and D. E. Bryant, 2004, "Performance of Three Resin Based Materials for Treating Uranium Contaminated Groundwater Within a PRB," in Journal of Hazardous Materials, 116:191-204.

Basin Water, 2008, www.basinwater.com, Basin Water, Inc., Rancho Cucamonga, California.

Bennett, P., D. Gandhi, S. Warner, and J. Bussey, 2007, "In Situ Reductive Dechlorination of Chlorinated Ethenes in High Nitrate Groundwater," in Journal of Hazardous Materials, 149:568-573.

Bidhendi, G. R. N, T. Nasrabadi, H. R. Sharif Vaghefi, and H. Hoveidi, 2006, "Biological Nitrate Removal from Water Resources," in International Journal of Environmental Science and Technology, 3:281-287.

Bilidt, H, 1985, "Use of Reverse Osmosis for Removal of Nitrate in Drinking Water," in Desalination, 53:225-230.

Bowman, R. H, 2005, "Reduction of Perchlorate and Nitrate in Groundwater Using a HollowFiber Membrane Biofilm Reactor (MBfR)," ISBN \#1-56034-120-3, in Proceedings of the 2005 National Ground Water Association Conference on MTBE and Perchlorate: Assessment, Remediation, and Public Policy, dated May 26-27, 2005, San Francisco, California.

Burge, S., and R. Halden, 1999, Nitrate and Perchlorate Removal from Groundwater by Ion Exchange, UCRL-ID-135639, Lawrence Livermore National Laboratory, Livermore, California.

Christensson, M., E. Lie, and T. Welander, 1994, "A Comparison Between Ethanol and Methanol as Carbon Sources for Identification," in Water Science and Technology, 30:83-90. 
Chung, J., B. E. Rittman, W. F. Wright, and R. H. Bowman, 2007, "Simultaneous Bio-Reduction of Nitrate, Perchlorate, Selenate, Chromate, Arsenate, and Dibromochloropropane Using a Hydrogen-Based Membrane Biofilm Reactor," in Biodegradation, 18:199-209.

Darbi, A., T. Viraraghavan, R. Butler, and D. Corkai, 2003, "Pilot-Scale Evaluation of Select Nitrate Removal Technologies," in Journal of Environmental Science and Health, Part A, 38:1703-1715.

DOE/RL-2006-24, 2006, Remedial Investigation Report for 200-ZP-1 Groundwater Operable Unit, Rev. 0, U.S. Department of Energy, Richland Operations Office, Richland, Washington.

DOE/RL-2007-28, 2008, Feasibility Study Report for the 200-ZP-1 Groundwater Operable Unit, Draft B, U.S. Department of Energy, Richland Operations Office, Richland, Washington.

Dushenkov, S., D. Vasudev, Y. Kapulnik, D. Gleba, D. Fleisher, K. C. Ting, and B. Ensley, 1997, "Removal of Uranium from Water Using Terrestrial Plants," in Environmental Science and Technology, 31:3468-3474.

Elmidaoui, A., F. Elhannouni, M. A. Menkouchi Sahlia, L. Chaya, H. Elabbassi, M. Hafsi, and D. Largeteau, 2001, "Pollution of Nitrate in Moroccan Ground Water: Removal by Electrodialysis," in Desalination, 136:322-325.

Environment Agency, 2005, Attenuation of Nitrate in the Sub-Surface Environment, Science Report SC030155/SR2, United Kingdom Environment Agency, Rotherham, England.

EPA, 2000, Cost and Performance Report - In Situ Permeable Reactive Barriers for Contaminated Groundwater at Fry Canyon, Southeastern Utah, dated January 2000, U.S. Environmental Protection Agency, Office of Solid Waste and Emergency Response, Washington, D.C. (http://costperformance.org/pdf/frycanyon.pdf).

EPA, 2004, "Biological PRB Used for Perchlorate Degradation in Ground Water," in Technology News and Trends, dated February 2004, U.S. Environmental Protection Agency, Technology Innovation Program, Washington, D.C.

EPA, 2006, "Biological PRB Application Expanded to Accelerate Perchlorate Degradation in Ground Water," in Technology News and Trends, dated July 2006, U.S. Environmental Protection Agency, Technology Innovation Program, Washington, D.C.

EPA, 2008, "SRNL Evaluates Sustainable Remediation Strategies for Metals and Radionuclides," in Technology News and Trends, 34:2-3.

EPA-542-R-03-009, 2004, Treatment Technologies for Site Cleanup: Annual Status Report, $11^{\text {th }}$ edition, U.S. Environmental Protection Agency, Office of Solid Waste and Emergency Response, Washington, D.C.

EPA/625/1-88/022, 1988, Design Manual: Constructed Wetlands and Aquatic Plant Systems for Municipal Wastewater Treatment, U.S. Environmental Protection Agency, Washington, D.C.

EPA 816-F-00-002, 2002, Implementation Guidance for Radionuclides, U.S. Environmental Protection Agency, Washington, D.C. 
EPA, Ecology, and DOE, 1995, Declaration of the Interim Record of Decision for the 200-ZP-I Operable Unit, \#016085, U.S. Environmental Protection Agency, Washington State Department of Ecology, and U.S. Department of Energy, Washington, D.C.

FRTR, 2002, Evaluation of Permeable Reactive Barrier Performance, revised report dated December 9, 2002, prepared for the Federal Remediation Technologies Roundtable (FRTR) by the Tri-Agency Permeable Reactive Barrier Initiative, U.S. Department of Defense, U.S. Department of Energy, and U.S. Environmental Protection Agency, Washington, D.C.

Hell, F., J. Lahnsteiner, H. Frischherz, and G. Baumgartner, 1998, "Experience with Full-Scale Electrodialysis for Nitrate and Hardness Removal," in Desalination, 117:173-180.

Henry, B. M., D. C. Downey, A. M. Love, A. Whallon, S. Moore, J.R. Gonzales, J. Gorden, and E. S. K. Becvar, 2004, "Performance Validation of a Mulch Biowall for Remediation of Chlorinated Ethenes," in Remediation of Chlorinated and Recalcitrant Compounds, The Fourth International Conference, May 24-27, 2004, Monterey, California.

Indusekhar, V. K., G. S. Trivedi, and B. G. Shah, 1991, "Removal of Nitrate by Electrodialysis," in Desalination, 84:213-221.

Istok, J. D., J. M. Senko, L. R. Krumholz, D. Watson, M. A. Bogle, A. Peacock, Y. J. Chang, and D. C. White, 2004, "In Situ Bioreduction of Technetium and Uranium in a NitrateContaminated Aquifer," in Environmental Science and Technology, 38:468-475.

ITRC, 2000, Emerging Technologies for Enhanced In situ Biodenitrification (EISBD) of NitrateContaminated Ground Water, dated June 2000, Interstate Technology and Regulatory Cooperation, Work Group Enhanced In Situ Biodenitrification Work Team, Boston, Massachusetts.

ITRC, 2005, Permeable Reactive Barriers: Leasons Learned/New Directions -Technical/Regulatory Guidelines, dated February 2005, The Interstate Technology \& Regulatory Council, Permeable Reactive Barrier Team, Boston, Massachusetts,

Korkisch, J., 1989, Handbook of Ion Exchange Resins - Their Application to Inorganic Analytical Chemistry, Taylor \& Francis, Ltd., United Kingdom.

Krauter. P., 2001, "Using a Wetland Bioreactor to Remediate Ground Water Contaminated Nitrate $(\mathrm{mg} / \mathrm{L})$ and Perchlorate $(\mu \mathrm{g} / \mathrm{L})$," in International Journal of Phytoremediation, 3:415-433.

Lathrop, S. B., W. T. Tharpe, H. E. Nuttall, and B. G. Turner, 2003, "Pilot-Scale Field Test Results of Enhanced In Situ Denitrification," in the In Situ and Onsite Bioremediation, Proceedings of the Seventh International In Situ and On-Site Bioremediation Symposium, dated June 2003, Orlando, Florida.

Lin, Y. F., S. R. Jing, D. Y. Lee, Y. F. Chang, and K. C. Shih, 2008, "Nitrate Removal from Groundwater Using Constructed Wetlands Under Various Hydraulic Loading Rates," in Bioresource Technology, issue dated March 31.

Menkouchi Sahli, M. A., M. Tahaikt, I. Achary, M. Taky, F. Elhanouni, M. Hafsi, M. Elmghari, and A. Elmidaouia, 2004, "Technical Optimization of Nitrate Removal from Ground Water by Electrodialysis Using a Pilot Plant," in Desalination, 167:359-360. 
Midaoui, A. E., F. Elhannouni, M. Taky, L. Chay, M. A. M. Sahli, L. Echihabi, and M. Hafsi, 2002, "Optimization of Nitrate Operation from Ground Water by Electrodialysis," in Separation and Purification Technology, 29:235-244.

Mohseni-Bandpi, A., and D. J. Elliott, 1998, "Groundwater Denitrification with Alternative Carbon Sources," in Water Science and Technology, 38:237-243.

Moon, H. S., J. Komlos, and P. R. Jaffé, 2007, "Uranium Reoxidation in Previously Bioreduced Sediment by Dissolved Oxygen and Nitrate," in Environmental Sicience and Technology, 41:4587-4592.

Murphy, A. P, 1991, "Chemical Removal of Nitrate from Water," in Nature, 350:223-225.

North, N. N., S. L. Dollhopf, L. Petrie, J. D. Istok, D. L. Balkwill, and J. E. Kostka, 2004, "Change in Bacterial Community Structure During In Situ Biostimulation of Subsurface Sediment Co-Contaminated with Uranium and Nitrate," in Applied and Environmental Microbiology, 70:4911-4920.

Parsons, 2004, Principles and Practices of Enhanced Anaerobic Bioremediation of Chlorinated Solvents, final report dated August 2004, prepared for Air Force Center of Environmental Excellence, Naval Facilities Engineering Service Center, and Environmental Security Technology Certification Program, Arlington, Virginia.

PNNL-15954, 2006, Screening of Potential Remediation Methods for the 200-ZP-1 Operable Unit at the Hanford Site, Rev. 0, Pacific Northwest National Laboratory, Richland, Washington.

Purolite, 2008, www.purolite.com, Purolite Corporation, Bala Cynwyd, Pennsylvania.

Reed, S. C., and D. Brown, 1995, "Subsurface Flow Wetlands - A Performance Evaluation," in Wat. Env. Res., 67:244-248.

Reilly, J. F., A. J. Horne, and C. D. Miller, 1999, "Nitrate Removal from a Drinking Water Supply with Large Free-Surface Constructed Wetlands Prior to Groundwater Recharge," in Ecological Engineering, 14(1-2):33-47.

Remco, 2008, www.remco.com, Remco Engineering, Ventura, California.

ResinTech, 2008, www.resintech.com, ResinTech, Inc., West Berlin, New Jersey.

Schipper, L., and M. Vojvodić-Vuković, 1998, "Nitrate Removal from Groundwater Using a Denitrification Wall Amended with Sawdust: Field Trial," in Journal of Environmental Quality, 27:664-668.

Schoeman, J. J., and A. Steyn, 2003, "Nitrate Removal with Reverse Osmosis in a Rural Area in South Africa," in Desalination, 155:15-26.

Sengupta, A. K., 1995, Ion Exchange Technology: Advances in Environmental Pollution Control, Technomic Publishing Co., Lancaster, Pennsylvania.

Senko, J. M., J. D. Istok, J. M. Suflita, and L. R. Krumholz, 2002, "In-Situ Evidence for Uranium Immobilization and Remobilization," in Environmental Science and Technology, 36:1491-1496. 
Suthersan, S. S., C. C. Lutes, P. L. Palmer, F. Lenzo, F. C. Payne, D. S. Liles, and J. Burdick, 2002, Final Technical Protocol for Using Soluble Carbohydrates to Enhance Reductive Dechlorination of Chlorinated Aliphatic Hydrocarbons, dated December 19, 2002, prepared by ARCADIS G\&M, Inc., Durham, North Carolina, for the Air Force Center for Environmental Excellence (Brooks Air Force Base, Texas) and the Environmental Security Technology Certification Program (Arlington, Virginia).

Takamichi, S., I. Satoshi, I. Masako, and T. Hiroshi, 2002, "In Situ Denitrification of NitrateContaminated Groundwater by Permeable Reactive Barrier," in Environmental Science, 15:305-309.

Tartakovsky, B., D. Millette, S. Delisle, and S. R. Guiot, 2002, "Ethanol-Stimulated Bioremediation of Nitrate-Contaminated Ground Water," in Ground Water Monitoring Review, 22(1):78-87.

Taylor, J., 2005, "City of Pomona Takes a Forward-Looking Approach to Leveraging Local Water Resources," in Journal AWWA, issue dated September 2005, pp. 50-54.

Wilkin, R. T., Hutchins, S. R., T. R. Lee, and B. T. Scroggins, 2006, Performance Evaluation of a Carbon-Based Reactive Barrier for Nitrate Remediation, RTDF1-5, presented at the Remediation Technologies Development Forum Meeting, October 11-13, 2006, Charleston, South Carolina.

Wilson, J. T., B. M. Henry, and E. S. K Becvar, 2007, Short Course-Enhanced Anaerobic Bioremediation Using Permeable Mulch Biowalls, presented at the $9^{\text {th }}$ International In Situ and On-Site Bioremediation Symposium, May 2007, Baltimore, Maryland.

WRT, 2008, www.wrtnet.com, Water Remediation Technology, LLC, Wheat Ridge, Colorado.

WSRC-TR-2002-00435, 2002, Laboratory Evaluation of I-129 and Tc-99 Removal at the F-Area Water Treatment Units, U.S. Department of Energy, Savannah River Site, Aiken, South Carolina.

WSRC-TR-2002-00571, 2002, Potential In situ Remediation of ${ }^{129}$ I and $^{99}$ Tc in Groundwater Associated with the F-Area Seepage Basins (U), U.S. Department of Energy, Savannah River Site, Aiken, South Carolina.

Wu, W. M., J. Carley, T. Gentry, M. A. Ginder-Vogel, M. Fienen, T. Mehlhorn, H. Yan, S. Caroll, M. N. Pace, J. Nyman, J. Luo, M. E. Gentile, M. W. Fields, R. F. Hickey, B. Gu, D. Watson, O. A. Cirpka, J. Zhou, S. Fendorf, P. M. Kitanidis, P. M. Jardine, and C. S. Criddle, 2006, "Pilot-Scale in Situ Bioremediation of Uranium in a Highly Contaminated Aquifer. 2. Reduction of U(VI) and Geochemical Control of U(VI) Bioavailability," in Environmental Science and Technology, 40:3986-3995.

Yirong, C., and U. Petpaiboon, 2004, "Performance of Constructed Wetland Treating Wastewater from Seafood Industry," in Water Science and Technology, 49:289-294.

Zhu, T., and F. J. Sikora, 1995, "Ammonium and Nitrate Removal in Vegetated and Unvegetated Gravel Bed Microcosms Wetlands," in Water Science and Technology, 32:219-228. 